Andrei Bravo Ponce 


\section{La creencia cristiana: su justificación en la actualidad}

\section{Introducción}

La presencia del pensamiento católico-cristiano en la realidad mexicana sigue siendo una parte importante del ideario personal de muchos mexicanos por ser parte de una tradición occidental que contempla creencias judías, griegas, romanas y cristianas. El desarrollo de la cultura en Occidente ha sido permeado, indudablemente, por la tradición de la religión cristiana. Gran parte de la idiosincrasia de las sociedades occidentales sigue conservando símbolos provenientes de la ideología cristiana. La inquietud surge sobre un tema que parecería obvio para la cultura occidental y particularmente para la cultura mexicana, precisamente por ese carácter de obviedad que se le otorga a un área de la cultura que aparece tan cercana al análisis y que, sin embargo, no tiene la suficiente crítica.

La pregunta por la actualidad del cristianismo atiende a un deseo de someter dicho sistema de creencias a una crítica actual, que discierna sus errores y aciertos. Los postulados cristianos siempre han sido defendidos desde sus defensores internos a la doctrina cristiana; sin embargo, resulta pertinente hacer de estos postulados un sistema de proposiciones que afirmen algo del mundo o contribuyan a conocer el mundo.

En esta investigación, el cristianismo se someterá al análisis crítico, mediante el que podrá concluirse una consideración más actual sobre la religión que más ha impactado en Occidente. El fin del trabajo relata un proceso dual: o bien el cristianismo es una mera fábula religiosa que ayuda a los hombres a olvidarse de sus problemas en la vida o bien resultará ser una herramienta útil para re-conocer el mundo y comprenderlo, abonando así a una actividad noble: conocer, replantear lo conocido y dudar. 


\section{Ponencia}

Desde su nacimiento, con la crucifixión de Jesús, la religión cristiana ha influenciado y transformado las sociedades y las creencias de millones de hombres.

No hay ámbito de la vida del hombre en la Tierra que no haya tenido una influencia del cristianismo. Desde la decisión histórica de dividir las eras en los años "antes de Cristo" y "después de Cristo", hasta en la división tripartita de los poderes del Estado, es clara la influencia de la religión.

Desde la oficialización del cristianismo en el Concilio de Nicea (325 d. C.), la práctica cristiana salió del ámbito personal para llevarse al público a través de los dogmas y las normas morales cristianas. El desenvolvimiento en tantas áreas de la vida humana ocasionado hasta ahora habla de la compleja imbricación que ha tenido el concepto de religión, con un origen cristiano-romano, en la cultura occidental.

\section{Algunas cifras}

De acuerdo con la Enciclopedia Británica, en el 2005, el 33.06\% (2 350 millones de personas) de la población en el mundo se consideraba cristiana. En el Anuario Pontificio 2016, se reportó que el 17.8\% (1 272 millones de personas) de la población mundial se consideraba católica. ${ }^{1}$

De acuerdo con el último censo poblacional del INEGI (2010), en México, de la población mayor de 5 años, había 94293 194 personas que practicaban una religión, contra 4660692 personas sin religión. De las personas religiosas, un $89.3 \%$ era católica, un $8.0 \%$ de esas personas eran cristianas protestantes y evangélicas, un $2.5 \%$ tenían religiones bíblicas pero diferentes a la evangélicas y un $0.2 \%$ practicaban otras religiones. ${ }^{2}$

1 Anuario Pontificio 2016, cifra de católicos en el mundo.Disponible en https:// press.vatican.va/content/salastampa/es/bollettino/pubblico/2016/03/05/ estadisticas.html

2 INEGI, "Estructura porcentual de la población que profesa alguna religión por tipo de religión”, Censo de Población y Vivienda 2010. Disponible en http://www.beta.inegi.org.mx/temas/religion/ 


\section{El cristianismo católico}

La presencia del pensamiento católico-cristiano en la realidad mexicana sigue siendo una parte importante del ideario personal de muchos mexicanos por ser parte de una tradición occidental que contempla creencias judías, griegas, romanas y cristianas. El desarrollo de la cultura en Occidente ha sido permeado, indudablemente, por la tradición de la religión cristiana. Gran parte de la idiosincrasia de las sociedades occidentales sigue conservando símbolos provenientes de la ideología cristiana. La inquietud surge sobre un tema que parecería obvio para la cultura occidental y particularmente para la cultura mexicana, precisamente por ese carácter de obviedad que se le otorga a un área de la cultura que aparece tan cercana al análisis y que, sin embargo, no tiene la suficiente crítica.

\section{Breve historia}

La religión cristiana inicia con la llegada de la "buena nueva" a la tierra de los hombres, mensaje traído por Jesús, quien tuvo por misión la difusión del inminente proceso de salvación.

Él predicaba que el reino de Dios estaba cerca y que los hombres podían entrar en él por medio del arrepentimiento y la fe en el evangelio ( $\mathrm{Mr} 1: 14-15)$. El arrepentimiento que Jesús requería era por la desobediencia a la ley de Dios. Esta ley estipulaba que los hombres debían amar a Dios por sobre todo y a su prójimo como a sí mismos (Mt 22:34-40). El amor es el cumplimiento de la ley. Cuando la desobediencia trae aparejada la falta de amor, el arrepentimiento restablece el equilibrio entre el hombre y Dios, y entre el hombre y su prójimo. ${ }^{3}$

Otra característica es la creencia en la Trinidad, que distingue tres entes separados que interactúan a la vez como el mismo Dios: Padre, Hijo y Espíritu Santo.

En el Credo de Nicea, se recopilan los elementos principales del catolicismo en una oración que resume y afirma la doctrina aceptada por los católicos.

3 Boer, Harry R., Historia de la iglesia primitiva. Una visión clara y precisa sobre los orígenes y la formación de la iglesia cristiana, Logoi, 2001, p. 11. 


\section{Creencia cristiano-católica}

Justificación. Es apremiante esclarecer el sentido que tiene una justificación. De acuerdo con la Real Academia Española, una justificación (del latín iustificatio) es una "prueba convincente de algo", por lo que la acción de justificar es "probar algo con razones convincentes, testigos o documentos"4.

Justificación de las creencias (que son proposiciones). Platón formuló la condición tripartita de una proposición conocida con el carácter de creencia verdadera y justificada. ${ }^{5}$ En la Suma Teológica, Tomás de Aquino asevera que "creer es el acto del entendimiento que asiente a la verdad divina imperado por la voluntad, a la que Dios mueve mediante la gracia." ${ }^{16}$ La definición de Platón es una respuesta filosófica porque parte de un argumento racional; la de Tomás de Aquino es teológica ya que inicia con un móvil de voluntad que determina la dirección de la creencia. Esto nos lleva a la distinción entre filosofía y teología.

Justificación por fe. Agustín de Hipona afirmó: Credo ut intelligam, intelligo ut credam ("Creo para entender mejor, y pienso para poder creer más y mejor”). Tomás de Aquino niega la teoría de la "doble verdad", pero reconoce que ambos medios tienen diferencias en cuanto a su método y su objeto de estudio: la filosofía será la encargada de investigar las verdades naturales del mundo a través de la luz de la razón, mientras que la teología se ocupará del conocimiento de las verdades provenientes de la revelación divina.

A Santo Tomás le parece que el destino del hombre es aspirar a las verdades sobrenaturales, que son el fin último que rebasa su naturaleza creada. Para conseguir esta trascendencia, el hombre necesita de la revelación.

\section{Dos modos del ser del cristianismo}

De la fe (teológico). Es la apelación a la autoridad divina que actúa sobre la voluntad del hombre.

4 Real Academia Española, consulta de “justificación” y “justificar”, en Diccionario de la Lengua Española, consultado en febrero de 2017.

5 Platón, Teeteto, p. 201.

6 Tomás de Aquino, Suma Teológica, II-II, q. 2, a. 9. 
Racional (filosófico). Reside, estructuralmente, en la argumentación.

$¿ Q u e ́$ sentido tiene hacer una investigación sobre la posible justificación filosófica de un conjunto de creencias construidas con base en la teología? La respuesta está en que la creencia cristiana no sólo se halla respaldada en una metodología teológica, sino que su justificación se encuentra muchas veces imbricada con supuestos metafísicos y filosóficos.

\section{Relaciones entre fe y razón en lo social}

La secularización es vista como un proceso doble y complementario de aprendizaje.

"Los ciudadanos secularizados, en tanto que actúan en su papel de ciudadanos del Estado, no pueden negar por principio a los conceptos religiosos su potencial de verdad, ni pueden negar a los ciudadanos creyentes su derecho a realizar aportaciones en lenguaje religioso a las discusiones públicas. Es más, una cultura política liberal puede incluso esperar de los ciudadanos secularizados que participen en los esfuerzos para traducir aportaciones importantes del lenguaje religioso a un lenguaje más asequible para el público general." (Habermas, Entre razón y religión)

\section{Conclusión}

Pretender una secularización ideológica tanto en las relaciones socio-políticas como en la discusión filosófica carece de sentido debido a la mutua implicación que tiene la ideología religiosa con el discurso racional de la filosofía. 